\title{
As crianças-soldados imersas na crise humanitária no Mali
}

\author{
Wanda Helena Mendes Muniz Falcão ${ }^{1}$
}

\section{Resumo}

Este trabalho analisa o uso de crianças nos conflitos armados. Especificamente, examina a crise humanitária instalada no Mali ao que tangencia as crianças-soldados, discutindo as circunstâncias existentes e os mecanismos para prevenção e combate a esta prática contemporânea.

Palavras-chave: Conflitos; Crise no Mali; Crianças-soldados.

A problemática envolta ao Mali passou a ser notícia de interesse internacional nos últimos meses. Mas, o que chamara tanta atenção? Situado ao norte do continente africano, o país mergulhado em crise humanitária revelou ao mundo as dificuldades do povo malês para sobreviver aos entraves político-religiosos na região. Destarte, as disputas pelo poder ensejou que militantes islâmicos dividissem o território, tomando o comando da parte norte do Estado, utilizando-se de escudos humanos para o êxito.

Com pouco mais de quinze milhões de habitantes, a República do Mali detém marcas históricas que lançam luz sob o cenário de hoje. Em tempos idos, fora centro de grandes fontes minerais, atraindo estrangeiros para seu território, no século XIX, colônia francesa. A população amarga anos de exploração, pobreza, analfabetismo e baixo

\footnotetext{
${ }^{1}$ Acadêmica do Curso de Direito da Faculdade de Ciências Sociais Aplicadas (FACISA), Campina Grande, PB. Membro do Núcleo de Estudos de Direito Internacional e Direitos Humanos da FACISA; do Grupo de Pesquisa "Pragmatismo e Realismo Jurídico" vinculado ao Programa de Pós-Graduação em Ciências Jurídicas da Universidade Federal da Paraíba (PPGCJ/UFPB), João Pessoa, PB; do Grupo de Pesquisa do Observatório de Direitos Humanos da Universidade Federal de Santa Catarina (UFSC), Florianópolis, SC. Pesquisadora do Centro de Direito Internacional (CEDIN), Belo Horizonte, MG. Associada ao Conselho Nacional de Pesquisa e Pós-graduação em Direito (CONPEDI). Estagiária do Ministério Público Estadual da Paraíba. E-mail: wanda.helenammf@bol.com.br

Conjuntura Global, Curitiba, Vol. 2, n.1, jan./mar., 2013, p. 39-42. 
desenvolvimento econômico - para não se falar em quase inexistência de aspectos industriais no país, com preponderância demográfica na zona rural.

Deste modo, a herança deixada pelo colonialismo e a torta independência no ano de 1960 contribuem substancialmente para o desenho social local. Além destes problemas de cunho político, há também efetivos empecilhos no tocante à formação cultural e religiosa do povo - multifacetada; as divergências ideológicas são latentes ao passo que este fator reforça a situação de instabilidade institucional. É a "175 a colocada entre 187 países avaliados pelo Índice de Desenvolvimento Humano (IDH) do Programa das Nações Unidas para o Desenvolvimento (PNUD) e cerca de 69\% da população vive abaixo da linha de pobreza" (UNIC RIO, 2013). O quadro é alarmante.

As etnias - com diferentes percepções históricas, filosóficas e religiosas, a exemplo de bambara, o soninke, o khassonké e malinka - são pulverizadas no território do Mali e se confrontam em alguns aspectos, pontualmente na ascensão ao poder do Estado. Logo, há de se falar em tentativas crescentes para tomada de mando no país.

A ausência de estabilidade, como dito anteriormente, é gravosa para o andamento pacífico do país. Em março de 2012 houve mais um golpe nas páginas da política malinesa: rebeldes declararam a independência do norte, agora Azawad, desencadeando, por conseguinte, o temor do Ocidente para uma nova - e robusta - rota do Islamismo (confundindo-se, equivocadamente, com atividades terroristas).

Inobstante a tomada do norte, o grupo continuara avançando rumo ao sul, entretanto, com a intervenção francesa - flashback para o neocolonialismo conseguiram-se frear os avanços nos primeiros meses de 2013. 0 governo Hollande e seus aliados enviaram tropas para atenuar - em melhor dicção: cessar - os ataques dos tuaregues do "Movimento Nacional para a Libertação de Azawad". Bamako, sua capital, em perigo pelas investidas islamitas, fora cercada pelos opostos à caminhada dos revoltosos. Com a presença militarista estrangeira, os locais envolvidos na luta armada fazem o uso de crianças-soldados.

Se as linhas belicosas já preocupavam a comunidade internacional, a investida em escudos humanos pueris veio a agravar o problema. Infelizmente, 
estamos vivendo um período excepcional de movimentação e colapso da ordem planetária, especialmente com a difusão de chefes guerreiros autônomos e de Estados fracassados. Esta mudança tornou possível uma nova maneira de guerrear. [...] Os grupos atraem as crianças por meio de técnicas de recrutamento que tiram vantagem do desespero das crianças e, às vezes, de sua imaturidade, ou meramente pelo bom e velho método do sequestro. (SINGER, 2008)

Nos períodos de guerra, as crianças sofrem intensamente, seja de forma direta amputações, mortes, desnutrição - seja indireta, os familiares envolvidos nos conflitos. Tristemente, esse fato se repete no Mali, pois "estima-se que 210 mil crianças malinesas estarão em risco de desnutrição aguda em 2013 e, 450 mil, de desnutrição moderada. [Em torno de] 15.506 foram admitidas em centros de tratamento contra a desnutrição" (ONU, 2013).

Fazer uso de crianças nos fronts é gravíssima infrigência aos direitos humanos, pois "[...] quando crianças inocentes são forçadas a participar como agentes desse flagelo, a coisa torna-se ainda mais revoltante. [...] A pobreza, a propaganda e os interesses ideológicos continuam a provocar o envolvimento de crianças em vários conflitos" (BINGEMER, 2013). No caso malês, muitas são as crianças no combate ao lado dos tuaregues, permitindo, assim, o ceifar da conceituação sobre a infância, marcando gerações futuras.

"Muitos desses jovens são recrutados à força, outros se alistam voluntariamente, porque quase não veem ou não têm outra alternativa de não participar da guerra" (KINDERNOTHILFE, 2013), são movidos por simbiose de sentimentos, sejam estes: vingança, dor, solidão. É preciso, de fato, mais ações que vislumbrem o combate a esta prática, a regeneração daqueles que saem da guerra com traumas e distorcidas visões sobre a vida e a sociedade com um todo.

Estas crianças, ora combatentes, devem ter proteção internacional, serem interesse de organismos que pretendam extinguir tais atitudes absurdas. 0 intento de observadores e dos Estados numa crise como a instalada no Mali, não deve ser tão somente por questões financeiras, políticas, mas também nos fatores humanitários, mormente às crianças. 
Há necessidade, portanto, de observância dos acordos firmados em prol da desmobilização de crianças-soldados $^{2}$, da criação e manutenção de políticas para a reintegração àquelas que sobrevivem aos $\operatorname{conflitos}^{3}$, de punição junto ao Tribunal Internacional Penal (TPI) aos que se utilizam de mecanismos de apreensão e força para o recrutamento.

\section{Referências bibliográficas}

BINGEMER, Maria Clara. Crianças soldado: a infância assassinada. Disponível em:

<http://amaivos.uol.com.br/amaivos09/noticia/noticia.asp?cod_noticia=11713\&co d_canal=47BINGEMER>. Acesso em: 28 fev. 2013.

KINDERNOTHILFE. Crianças-soldado: vítima e réu ao mesmo tempo. Disponível em:<http://br.kindernothilfe.org/Rubrik_Criancas_soldadas_html.html>. Acesso em: 02 mar. 2013.

ONU. Crise no Mali. Disponível em:

<http://www.onu.org.br/mali/relatorio-sobre-a-situacao-no-mali/>. Acesso em: 01 mar. 2013.

SINGER, Peter W. Os novos filhos da guerra. Air and Space Power Journal [online]

v. 20, n. $03, \quad 3^{\circ}$ trimestre, 2008. Disponível em:< http://www.airpower.maxwell.af.mil/apjinternational/apj-

p/2008/3tri08/singer.htm>. Acesso em: 02 mar. 2013.

UNIC RIO. Entenda as crises [Mali]. Disponível em:

<http://unicrio.org.br/onu-lanca-sites-em-portugues-sobre-crises-na-siria-e-nomali/>. Acesso em: 28 fev. 2013.

\footnotetext{
2 Vide Convenção Internacional sobre os Direitos da Criança aprovada na Resolução 44/25 da Assembléia Geral das Nações Unidas, em 20 de novembro de 1989.

${ }^{3}$ A criação do "Dia Internacional Contra a Utilização de Crianças - soldados" (dia 12 de fevereiro) faz parte de uma das expressões - formas - para alerta e combate ao fenômeno. Porém, é preciso ter-se ações mais contundentes para efetiva extinção de tal prática.

Conjuntura Global, Curitiba, Vol. 2, n.1, jan./mar., 2013, p. 39-42. 